\title{
Medical ethics and human rights in wartime
}

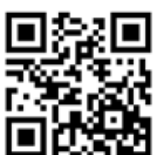

The ethical obligations of physicians to respect and protect the human rights of all people are well articulated in international medical ethics statements. For example, the World Medical Association (WMA)'s Declaration of Geneva (1948) obligates physicians to swear that 'I will not use my medical knowledge contrary to the laws of humanity.'

Dr Wouter Basson was charged with violating this medical ethics norm during the time he was in the military working with Project Coast and Delta G, specifically by 'leading a process where chemical substances for warfare were manufactured, weaponized and provided for use in combat, kidnapping and suicide.' The Professional Conduct Committee (PCC), charged with deciding whether he should retain his licence to practise medicine, relied primarily on the Declaration of Geneva, the WMA's Regulations in Time of Armed Conflict $(1956,1983)$, to identify medical norms of conduct that he violated ('Medical ethics in the time of armed conflict is identical to medical ethics in the time of peace ...), and the United Nations Convention on Biological and Toxin Weapons (1972) (prohibiting the development or production of any biological agents or toxins). The PCC was also powerfully aided in its careful articulation of medical ethics norms by the testimony of an international expert on wartime medical ethics from the USA, Dr Steven Miles. The PCC described Miles as the outstanding expert on the conventions and medical ethics' and as 'fair' and 'highly professional.

Basson defended himself by arguing that he was not bound by medical ethics during wartime or when under military orders, that he was acting as a soldier not a doctor, that he was not in a doctorpatient relationship, that he did not know that there were medical ethics codes that prohibited his actions, and that the medical ethics of the 1980s was different from today's medical ethics. While the PCC did not cite the precedent, these arguments were substantially identical to those that were used by the Nazi doctors to defend their conduct at the 1946 - 1947 Nuremberg Doctors' Trial (which was a criminal trial, with a higher standard of proof than a civil trial for licensure revocation) and that were rejected by the US judges presiding over that trial. The PCC specifically held, among other things, that 'in South Africa, the medical ethics during war and peace are identical'; that a doctor is responsible for his own actions and cannot escape responsibility by relying on a military order; that as long as a doctor retains his licence he is required to follow medical ethics; and that the absence of a doctor-patient relationship does not relieve the physician of his ethics obligations to the public.

I find all these conclusions reasonable and responsible, but in my opinion the most important and instructive conclusion of the PCC is that if a military physician wants to put military actions before his or her medical obliation to do no harm, he or she must resign from being a physician. In the PCC's words, only after the physician 'de-register[s] from the council ... will [he or she] be relieved of the privileges and responsibilities of a doctor'. The PCC did not add, but I think it is implicit, that there is no returning to the practice of medicine after this decision has been made.

Outside of South America, it has been relatively rare for licensing boards to charge physicians with war crimes or crimes against humanity.
The UK has taken action against a military physician who acted as an accessory to torture in Iraq (under Saddam Hussein), and another who failed to report suspected torture of prisoners while serving with the UK military in Afghanistan. No state licensing body in the USA has taken any action against US military or CIA physicians who have participated in torture or inhuman treatment of prisoners at CIA black sites and Guantanamo Bay. This is shameful, although somewhat understandable as the US government has done all it can to keep the identities of the physicians working for and with the CIA and the US military a secret. Even with the release of the US Senate Intelligence Committee Report on Torture ${ }^{[1]}$ in late 2014, which describes torture committed by US physicians and other health professionals at the 9/11 CIA black sites in excruciating detail, the identities of all but two contract psychologists remain secret. This is unacceptable. As the UN High Commissioner for Human Rights said in commenting on the report before the UN Human Rights Council in March 2015, the report is 'courageous and commendable' but must be 'followed through with real accountability ... torture cannot be amnestied. ${ }^{[2]}$

For most Americans it is especially painful to recall Archbishop Desmond Tutu's words shortly after 9/11 when Guantanamo Bay prison was opened: 'I never imagined I would live to see the day that the USA and its satellites would use precisely the same arguments that the apartheid government used for detention without trial. It's disgraceful. Archbishop Tutu was and is correct; and it is just as disturbing to see Basson using the same excuses for his actions that the Nazi physicians used to justify theirs. Americans always knew we had much to learn from Archbishop Tutu; now we know we have more yet to learn from South Africa's PCC.

Restricting physicians who have engaged in crimes against humanity from practising medicine is done not to punish them (that is the purpose of a criminal trial), but to protect the public and the medical profession. Physicians are licensed by the state to practise medicine for the benefit of the public and individual patients, and we must all trust ourselves and our health to them. When that trust is betrayed and physicians use their skills to harm at the direction of the state, it is a matter of protecting the integrity of the medical profession, as well as a form of selfdefence for potential patients, that their privilege to practise a healing profession be revoked or restricted.

\section{George J Annas}

Warren Distinguished Professor and Chair of the Department of Health Law, Bioethics and Human Rights, Boston University School of Public Health, Mass, USA annasgj@bu.edu

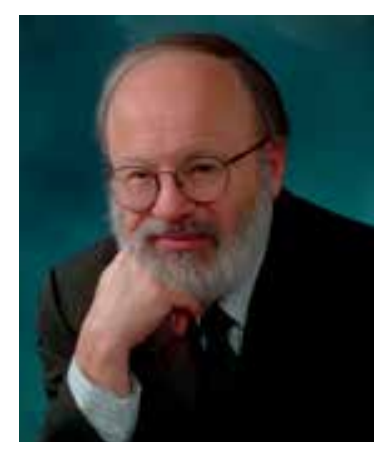

1. Report of the US Senate Intelligence Committee on Torture (released December 2014). http://www intelligence.senate.gov/study2014/sscistudy1.pdf (accessed 9 March 2015).

2. United Nations Human Rights. Opening Statement, Item 2, High Commissioner's Annual Report hittp://www.ohchr.org/EN/NewsEvents/Pages/DisplayNews.aspx?NewsID $=15642 \&$ LangID $=\mathrm{E}$ (accessed 9 March 2015).

S Afr Med J 2015;105(4):240. DOI:10.7196/SAMJ.9529 